\title{
Blood Sugar Level Monitoring
}

\author{
Rok Ražman, Aleksander Sešek, Jurij Tasič, Janez Trontelj \\ University of Ljubljana, Faculty of Electrical Engineering, Ljubljana, Slovenia
}

\begin{abstract}
Blood glycemic level, also known as blood sugar level or blood glucose level, especially that reaching high values (hyper glycaemia) and persisting in time, is strongly linked to the development of type 2 diabetes and consequently serious medical conditions such as neuropathy, cardiovascular diseases, sensitivity to infections etc. Nowadays the only effective and reliable way of monitoring blood sugar level is to directly analyze the blood (capillary or venous), interstitial or other body fluids. The former method is the most used. Its main disadvantage is puncturing of patient skin (finger pricking for example) which frequently causes pain and the risk of viruses and bacteria entering the body. The development of an effective and accurate noninvasive method for blood glucose monitoring has been recognized as a crucial goal for future studies of blood sugar and implementations of such methods into wearable devices. In this paper, we propose monitoring of blood glucose level employing skin impedance measurement. A measurement system featuring an Application-Specific Integrated Circuit (ASIC) is presented and analyzed. The fabricated ASIC in $350 \mathrm{~nm}$ CMOS technology with dimensions $1223 \mu \mathrm{m} \times 1388 \mu \mathrm{m}$, typically consumes $450 \mu \mathrm{A}$ at $3.3 \mathrm{~V}$ supply voltage and operates in frequency region from $5 \mathrm{kHz}$ to $16 \mathrm{MHz}$. The system exhibits a good linear response for loads up to a few $\mathrm{k} \Omega$, making it suitable for skin impedance measurements.
\end{abstract}

Keywords: blood sugar; bioimpedance; noninvasive method; ASIC

\section{Merjenje ravni krvnega sladkorja}

\begin{abstract}
Izvleček: Dlje časa trajajoča povišana raven krvnega sladkorja oziroma raven glukoze v krvi je tesno povezana s pojavom diabetesa ali sladkorne bolezni tipa 2 in posledično resnih zdravstvenih težav kot so nevropatija, srčno-žilne bolezni, nagnjenost k okužbam itd. Dandanes edini učinkovit in zanesljiv način merjenja krvnega sladkorja je neposredna analiza krvi (kapilarne ali venozne), intersticijske in drugih telesnih tekočin. Najpogostejša je prva omenjena metoda. Njena glavna slabost je prebadanje pacientove kože (npr. blazinic na prstih), ki pogosto povzroča bolečino in predstavlja tveganje, saj lahko virusi in bakterije prodrejo v telo. Razvoj učinkovite in natančne neinvazivne metode za merjenje ravni krvnega sladkorja je bil prepoznan kot ključni korak za bodoče študije krvnega sladkorja in implementacije takih metod v prenosne naprave. V tem prispevku je predstavljeno merjenje ravni krvnega sladkorja na osnovi merjenja impedance kože. Merilni sistem z integriram vezjem (ASIC) je predstavljen in analiziran. Izdelano integrirano vezje $v$ 350 nm CMOS tehnologiji z dimenzijami $1223 \mu \mathrm{m}$ x $1388 \mu \mathrm{m}$ tipično troši $450 \mu \mathrm{A}$ pri napajalni napetosti 3,3 V in deluje $v$ frekvenčnem razponu $5 \mathrm{kHz}$ do $16 \mathrm{MHz}$. Sistem izkazuje dober linearni odziv za bremena do nekaj k $\Omega$, kar je primerno za meritve impedance kože.
\end{abstract}

Ključne besede: krvni sladkor; bioimpedance; neinvazivna metoda; ASIC

*Corresponding Author's e-mail: rok.razman@fe.uni-lj.si

\section{Introduction}

Insight into the human body, its internal structures, processes and functions is a relatively young invention. It could be, without exaggeration, labeled a revolution in terms of medicine. During the whole history of humankind, the actual processes in the human body were a mystery and often explained by supernatural forces and other theories (for example the four humors: blood, yellow bile, black bile and phlegm).

The only way to study the internal composition of the human body was dissection of cadavers (which for a long time was banned due to religious conventions).
The above-mentioned method was not applicable to live patients and therefore their diagnosis was often not possible.

The development of science, engineering, physics, medicine etc. allowed the creation of so-called noninvasive methods for the study of the human body. One of those revolutionary methods was the discovery of X-ray imaging by Roentgen in 1895. In the 20th century, new inventions followed, like the CT (Computed Tomography scan) and Magnetic Resonance Imaging (MRI). These methods are focused on the internal structure of the body (bones, organs etc.). 
The same principle was applied also to body functions and mechanisms, some noteworthy methods are pulse oximetry [1], electroencephalography (EEG) [2], electrocardiography (ECG) [3], pulse transmit time [4] and others.

Biompedance analysis of body tissues, especially skin, has been proposed as a noninvasive tool for healing process monitoring in tissue transplants [5] blood glucose [7], [8], skin cancer identification [9], body composition determination [10] etc.

Diabetes mellitus is a chronic metabolic diseases characterized by raised blood sugar or glycaemia. Undiagnosed and untreated diabetes has severe consequences for health. It causes various complications, for example vision loss (retinopathy), nerve damage, increased risk of cardiovascular, peripheral vascular and cerebrovascular disease, foot ulcers, limb amputation, kidney disease (nephropathy) [11] etc.

The estimated number of people affected by diabetes rose from 108 million in 1980 to 422 million in 2014 [12]. One of two adults with diabetes is undiagnosed [13].

Diabetes and the conditions directly caused by it is a burden to people affected, their families, national health systems and national economies [12]. The estimated cost of diabetes treatment in the United States of America in 2017 was $\$ 327$ billion, of which $\$ 237$ billion in direct cost and $\$ 90$ billion in reduced productivity. Every fourth of health care dollar in the USA is spent for diabetes [14].

Early diagnosis or detection of diabetes and prompt treatment of the disease are, beside diabetes prevention, two crucial ways to improve the health and assure longevity to the patients [12].

Continuous blood glucose monitoring is necessary for a better managing of the disease. Nowadays portable glucose meters are employed by patients to monitor their blood glucose level at home. Skin must be punctured with a lancet to obtain a droplet of capillary blood, which is applied to a disposable strip inserted into the glucose meter (Figure 1). Although this method is precise, it is invasive and consequently it causes pain, discomfort, it poses the risk of contamination with blood borne pathogens (viruses, bacteria). Many patients tend to skip individual blood glucose measurements or totally refrain from SMBG (Self Measurement of Blood Glucose) [15] rendering the treatment of diabetes less effective.

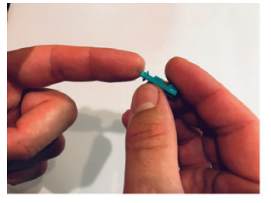

a)

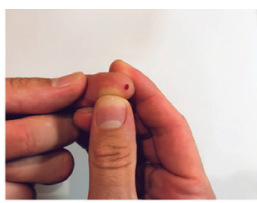

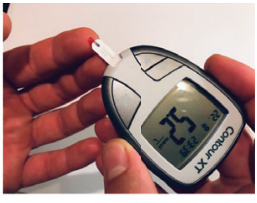

Figure 1: a) skin puncturing/pricking with a lancet, b) obtaining of a droplet of capillary blood and c) blood glucose determination with a portable glucose meter.

This paper proposes a noninvasive blood glucose level monitoring (measurement) system based on an ASIC. Chapter 2 presents the architecture of the proposed system (beside the ASIC it features also a custom PCB, a microcontroller and a Graphical User Interface (GUI)). Chapter 3 presents some information about the system response and Chapter 4 provides the main conclusions and results of presented work.

\section{System design}

The proposed noninvasive system is centered around a fully integrated analog front-end (AFE) which is based on synchronous bioimpedance measuring. The circuitry injects an AC current into the subject under test (SUT), in this case human skin, and the voltage potential across the SUT is measured, pre-amplified, multiplied with inphase and quadrature signal and finally filtered to obtain the real and imaginary part of impedance.

\section{$2.1 \mathrm{ASIC}$}

The AFE was implemented in an ASIC. Figure 2 presents a simplified schematic of the ASIC. Voltage excitation through buffers buf and external resistors Rexc form a current source (pads EXCP and EXCN). The AC current is injected into the skin through a pair of electrodes and the resulting voltage potential across the electrodes is sampled (IM_P and IM_N). DIA_BP is a differential band-pass instrumentation amplifier, which amplifies the voltage drop on the SUT, in this case skin.

Excitation voltage is either generated internally by digital ring oscillator (DRO) or supplied by an external signal generator. The core of the DRO (Figure 4) is a ring of inverters and capacitors. A reference current source is generated by Iref and is mirrored by Imir to the inverters. Imir is composed by 4 current mirrors with binary weighted dimensions. The inverter ring output signal osc_out is fed to a series of 7 dividers. Each divider reduces the osc_out frequency (fosc_out) by a factor of two. Thus, the last divider yields a frequency equal to fosc_out/27. The output frequency osc_clk is chosen with a 8:1 multiplexer (MUX 8:1). 
The oscillator generates square wave pulses with frequencies in the range $\mathrm{fmin}=20 \mathrm{kHz}$ to $\mathrm{fmax}=14.24 \mathrm{MHz}$. It is controlled by an 8-bit register ( 4 bits for Imir and 3 bits for MUX 8:1, 1 bit is free) which in turn is controlled externally via SPI (in the schematic marked as SPI_cfg). The clk_sel block is used to switch between the clock sources.

Figure 3a) represents the ASIC layout designed in Cadence Virtuoso in $350 \mathrm{~nm}$ CMOS technology. The chip size is $1223 \mu \mathrm{m} \times 1388 \mu \mathrm{m}$. The core of the chip is composed by the AFE containing an Serial Peripheral Interface (SPI) block, a differential instrumentation amplifier, an I/Q block (in-phase/quadrature clock generator), two multipliers, two low-pass filters, two unity gain amplifiers, a bias and references block, a multi-frequency generator block etc. The core is surrounded by the bonding pads (from top left corner clockwise: vss, EN_TIM, vdda, CLK_OUT, EXCN, EXCP, OUQ, SSn, SCLK, VBAL, EXT_SEL, MOSI, MISO, OUI, SIGN, SIGP, EXT_CLK).

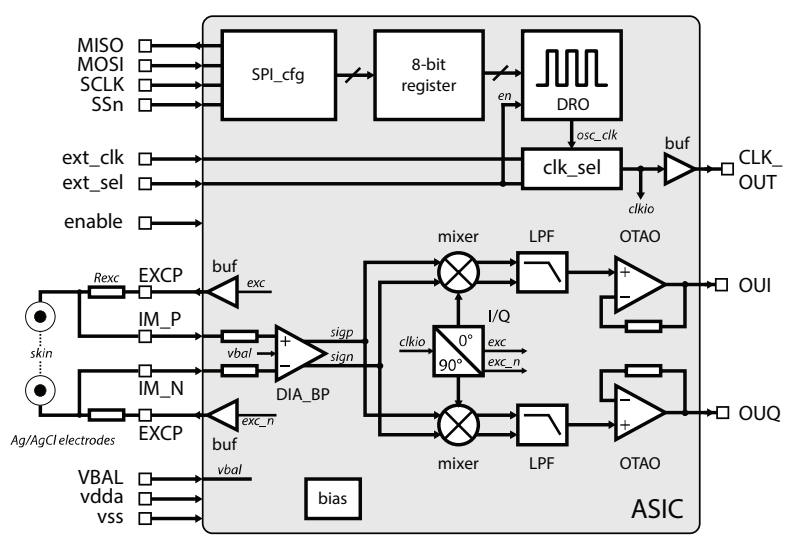

Figure 2: ASIC schematic.

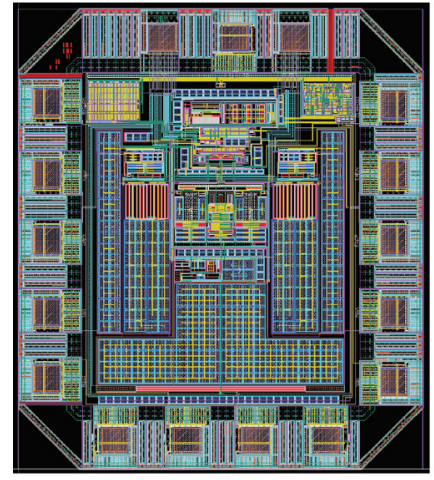

a)

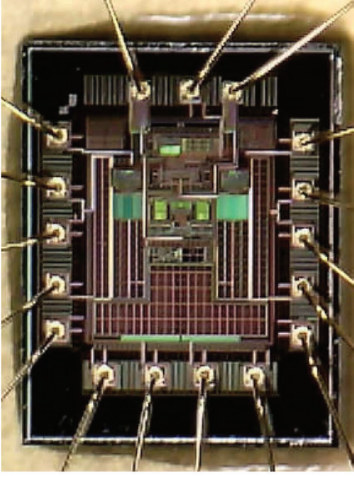

b)
Figure 3: a) ASIC layout and b) fabricated ASIC.

Figure $3 b$ ) represents the fabricated ASIC placed in a 20-pin ceramic dual in-line package (DIP) and bonded with gold wires. Furthermore the chip could be placed in a smaller surface mount package, for example SOIC-
18 to significantly reduce the ASIC's footprint on a Printed Circuit Board (PCB).

\section{$2.2 P C B$}

A PCB has been designed in Altium Designer and fabricated with a milling machine (Figure $5 \mathrm{a}$ ). The PCB has the all necessary connectors, decoupling capacitors, external resistors, etc. required by the ASIC.

\subsection{Microcontroller}

The SAMD21 Xplained Pro Evaluation Kit containing SAMD21J118A microcontroller by Atmel (now Microchip) serves as a bridge between the ASIC's SPI and a personal computer (Figure 5b). It also samples OUI and OUQ signals and provides voltage supply ( $3.3 \mathrm{~V}$ ) to the $\mathrm{PCB}$ and $\mathrm{ASIC}$.

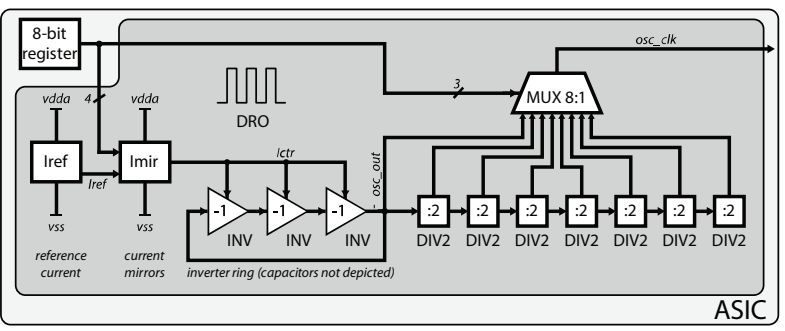

Figure 4: DRO schematic.

\section{$2.4 G U I$}

The system includes the ASIC, the PCB, and the microcontroller, which was firstly controlled by a Matlab script. Subsequently to facilitate the user experience a GUI has been developed using Visual Studio 2015 in C\# language (Figure 6). The total size of the setup file setup.exe is $774 \mathrm{~KB}$.

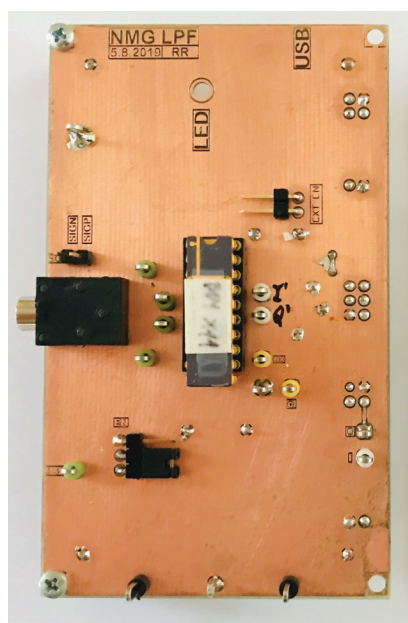

a)

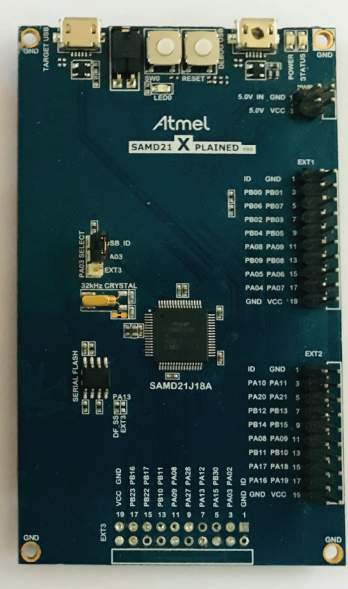

b)
Figure 5: a) PCB and b) microcontroller. 


\subsection{Skin interface}

The employed electrodes are Skintact T-60 by Leonhard Lang $\mathrm{Gmbh}$, which are $\mathrm{Ag} / \mathrm{AgCl}$ wet electrodes. Figure $7 \mathrm{a}$ ) represents the placement of the electrodes (the distance between the centers of the electrodes is $60 \mathrm{~mm}$ ), figure $7 \mathrm{~b}$ ) is an in-vivo placement of the electrodes on the left arm of a subject.

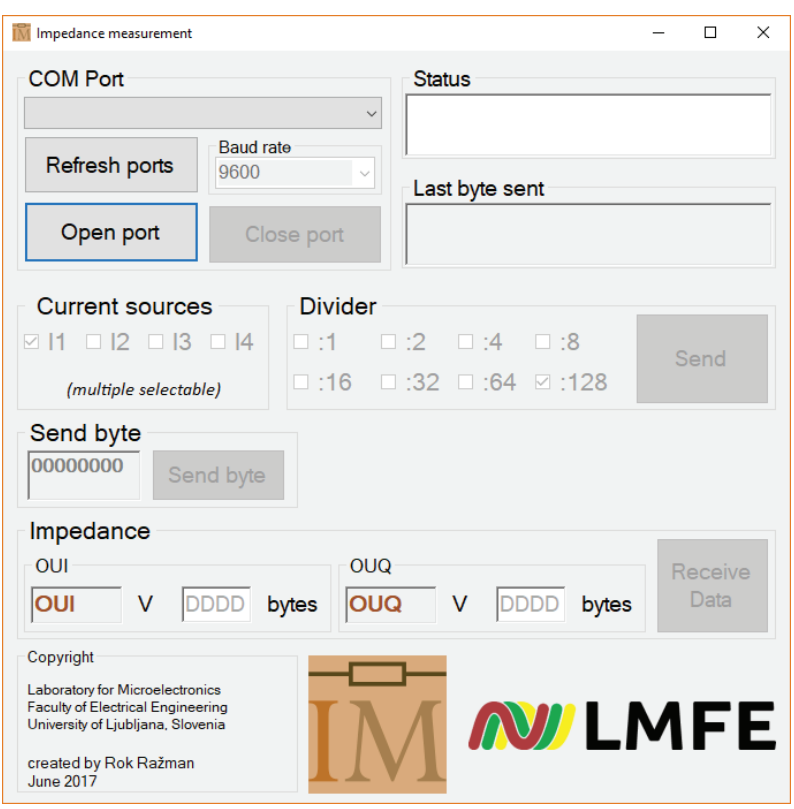

Figure 6: Graphical User Interface.

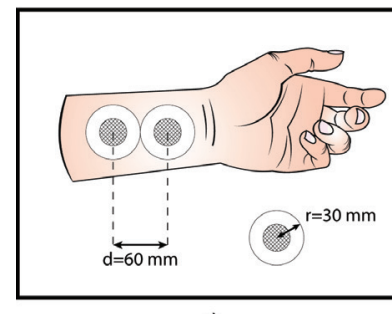

a)

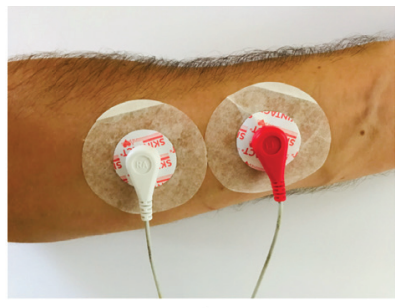

b)
Figure 7: Electrodes placement.

\subsection{System linearity}

The system exhibits good linearity for small loads (Figure 8), while for large loads it shows a significant nonlinearity (Figure 9). Due to this error, the calibration of the system prior to measurements is required (Figure 10). The calibration is achieved simply by substituting

the target SUT (human skin) with a series of resistors with small tolerance and measuring the system response signals OUI and OUQ at the desired excitation frequencies. Theoretically, OUQ should be equal to zero, while OUI should be linearly proportional to the resistor resistance value.

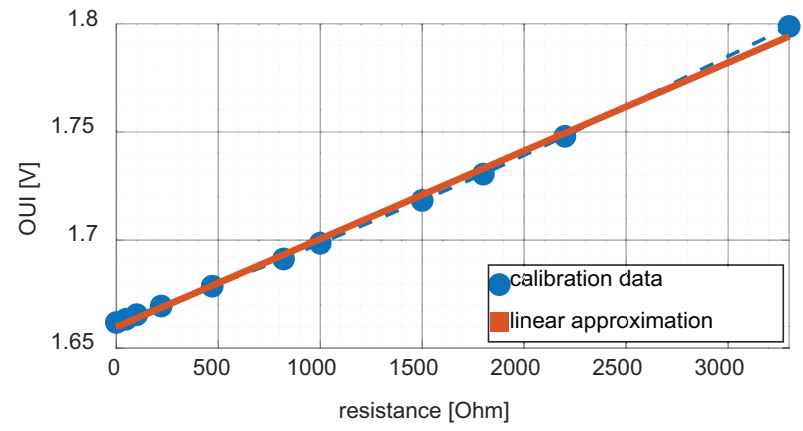

Figure 8: Linearity for loads $0-3.3 \mathrm{k} \Omega$.

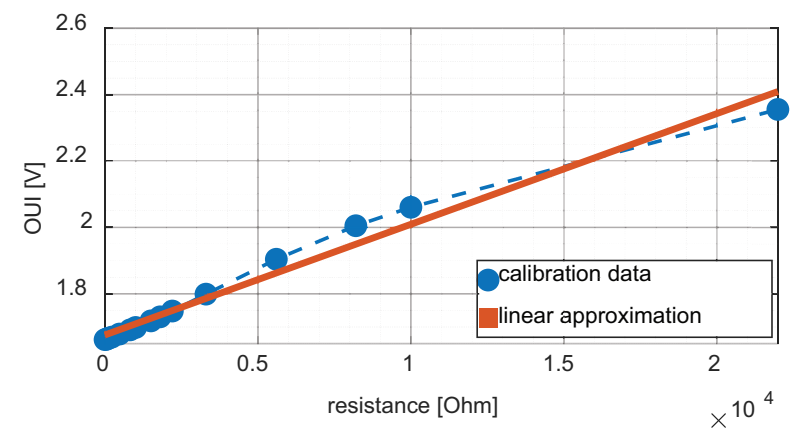

Figure 9: Linearity for loads $0-22 \mathrm{k} \Omega$.

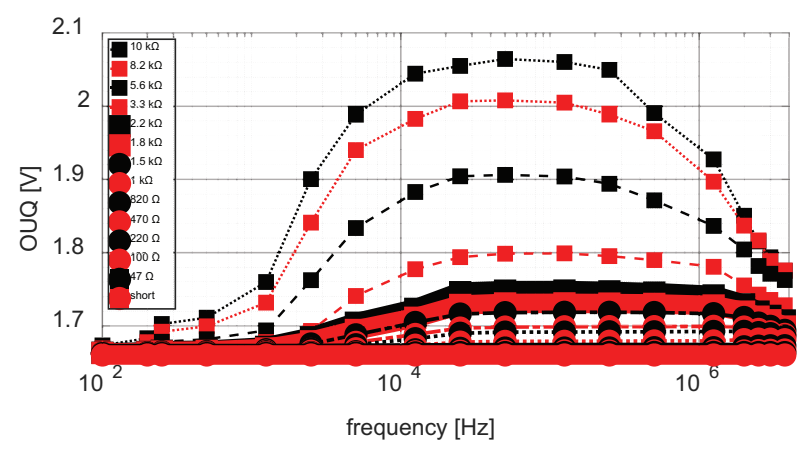

Figure 10: System calibration with resistors $0-10 \mathrm{k} \Omega$.

\section{Blood glucose vs impedance}

A series of measurements has been performed to quantify the effect of increased blood glucose level on skin impedance. Measurements (simultaneously with a glucose meter and the proposed noninvasive system) have been done before ingesting a dose of $75 \mathrm{~g}$ of glucose (equal to fasting blood glucose) and after that, which is known as Oral Glucose Tolerance Test (OGT). The selected time slots of measurement were time -30 minutes presents measurement when electrodes were placed, 0 minutes when glucose was ingested orally and then measurements were performed 15 minutes, 30 minutes, 60 minutes, 90 minutes and 120 minutes after glucose ingestion. 
Figure 11 represents the OGT of two subjects measured with our system and the corresponding blood glucose levels (BGL) in the legend in the upper right corner. Figures 11.a) and 11.b) were recorded for a female subject (in-phase and quadrature components respectively). Figures 11.c) and 11.d) correspond to a male subject. The measurements, which belong to the highest $\mathrm{BGL}$, are marked with five-point stars.

The female subject exhibits an increased OUI around $100 \mathrm{kHz}$, which can be correlated to high BGL. The male subjects does not exhibit any peaks, but shows an increased OUI for high BGL (except for $30 \mathrm{~min}$ ). The OUQ in both cases steadily decreases with time and it is not influenced by BGL.

\section{Conclusions}

In the paper, a noninvasive blood glucose measurement system has been presented. Preliminary analysis of the results (Figure 11) shows that variations of skin impedance are observable before and after glucose ingestion. The interindividual differences of skin impedance during the glucose tests are large and a simple equation or algorithm for blood glucose estimation cannot be formulated without taking in account a large number of factors which affect skin impedance, including electrode-skin impedance, electrode type, stratum corneum thickness, sweat glands density, hair follicles, variations of impedance, water content of skin [16] etc.
Resorting to a multisensory system would significantly benefit to the accuracy and selectivity of the proposed system. In addition, a larger group of subjects must be included in future studies and a multivariate analysis must be performed to obtain higher accuracy.

\section{Acknowledgments}

The authors would like to express their gratitude to the staff of the Laboratory of Microelectronics FE, University of Ljubljana for their help.

\section{Conflict of interest}

The authors declare no conflict of interest.

\section{References}

1. H. Lee, H. Ko, and J. Lee, 'Reflectance pulse oximetry: Practical issues and limitations', ICT Express, vol. 2, no. 4, pp. 195-198, Dec. 2016. https://doi.org/10.1016/j.icte.2016.10.004

2. M. Sawan et al., 'Wireless Recording Systems: From Noninvasive EEG-NIRS to Invasive EEG Devices', IEEE Trans. Biomed. Circuits Syst., vol. 7, no. 2, pp. 186-195, Apr. 2013. https://doi.org/10.1109/TBCAS.2013.2255595
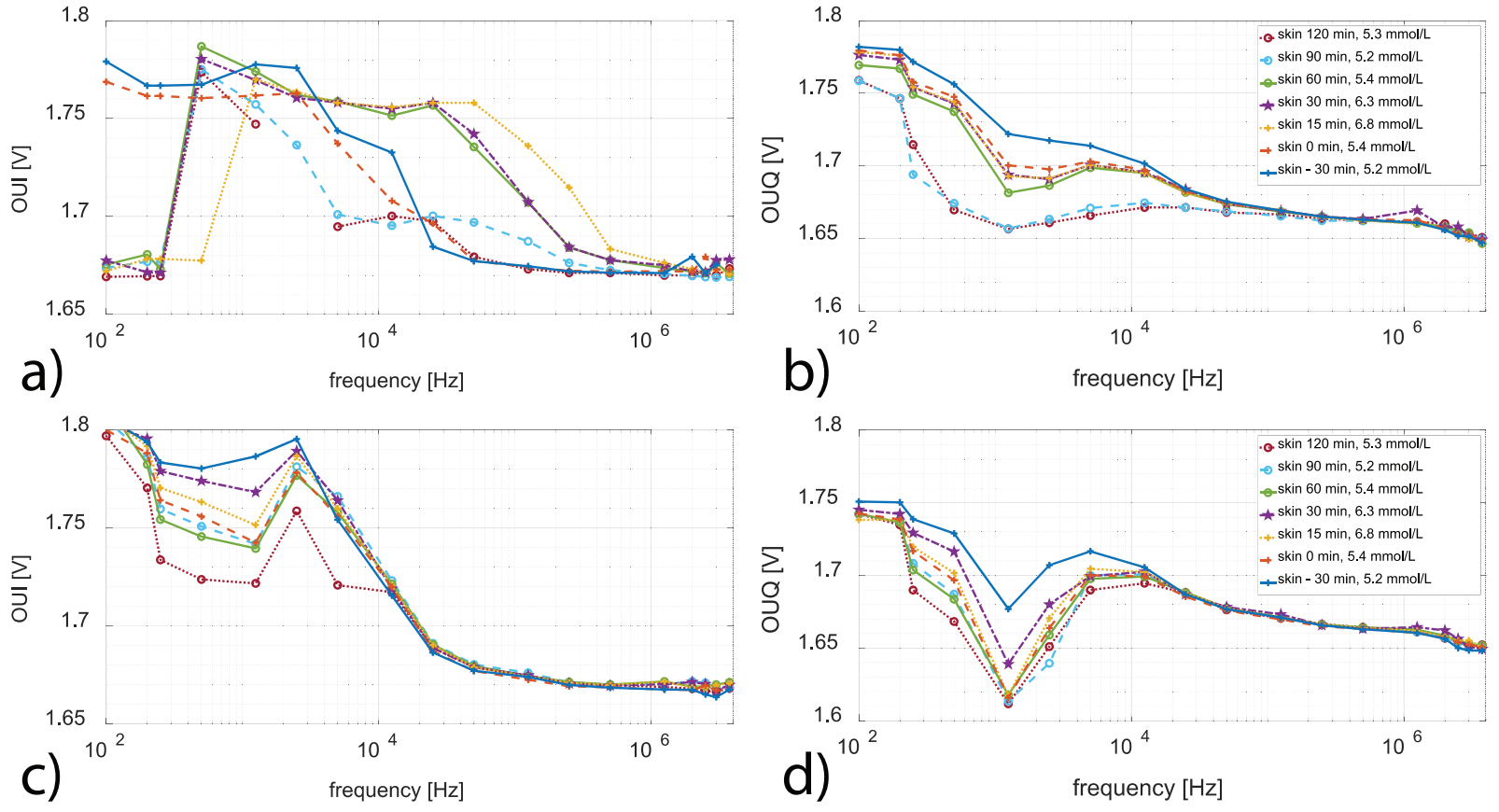

Figure 11: Skin impedance (I and Q component respectively) of the a-b) female subject, c-d) male subject. 
3. J. Liu and Y. Zhou, 'Design of a Novel Portable ECG Monitor for Heart Health', in 2013 Sixth International Symposium on Computational Intelligence and Design, 2013, vol. 2, pp. 257-260. https://doi.org/10.1109/ISCID.2013.178

4. B. Ibrahim, A. Akbari, and R. Jafari, 'A novel method for pulse transit time estimation using wrist bio-impedance sensing based on a regression model', in 2017 IEEE Biomedical Circuits and Systems Conference (BioCAS), 2017, pp. 1-4. https://doi.org/10.1109/BIOCAS.2017.8325054

5. M. Min, P. Annus, R. Land, T. Paavle, E. Haldre, and R. Ruus, 'Bioimpedance Monitoring of Tissue Transplants', in 2007 IEEE Instrumentation Measurement Technology Conference IMTC 2007, 2007, pp. 1-4.

https://doi.org/10.1109/IMTC.2007.379341

6. I. Bodén, D. Nilsson, P. Naredi, and B. LindholmSethson, 'Characterization of healthy skin using near infrared spectroscopy and skin impedance', Med. Biol. Eng. Comput., vol. 46, no. 10, p. 985, Oct. 2008.

https://doi.org/10.1007/s11517-008-0343-x

7. C. J. Cordero, L. C. L. Landicho, J. C. D. Cruz, and R. G. Garcia, 'Quantifying blood glucose level using S11 parameters', in TENCON 2017 - 2017 IEEE Region 10 Conference, 2017, pp. 1481-1486. https://doi.org/10.1109/TENCON.2017.8228091

8. C. E. Ferrante do Amaral and B. Wolf, 'Current development in non-invasive glucose monitoring', Med. Eng. Phys., vol. 30, no. 5, pp. 541-549, Jun. 2008.

https://doi.org/10.1016/j.medengphy.2007.06.003

9. P. Aberg, I. Nicander, J. Hansson, P. Geladi, U. Holmgren, and S. Ollmar, 'Skin cancer identification using multifrequency electrical impedance-a potential screening tool', IEEE Trans. Biomed. Eng., vol. 51, no. 12, pp. 2097-2102, Dec. 2004. https://doi.org/10.1109/TBME.2004.836523

10. M. A. Riyadi, A. N. Muthouwali, and T. Prakoso, 'Design of automatic switching bio-impedance analysis (BIA) for body fat measurement', in 2017 4th International Conference on Electrical Engineering, Computer Science and Informatics (EECSI), 2017, pp. 1-5. https://doi.org/10.1109/EECSI.2017.8239105

11. K. G. Alberti and P. Z. Zimmet, 'Definition, diagnosis and classification of diabetes mellitus and its complications. Part 1: diagnosis and classification of diabetes mellitus provisional report of a WHO consultation', Diabet. Med. J. Br. Diabet. Assoc., vol. 15, no. 7, pp. 539-553, Jul. 1998.

https:/doi.0rg/10.1002/(SIC)1096-9136(199807)15:7<539:AID-DIA668>3.0.C0;2-S

12. G. Roglic and World Health Organization, Eds., Global report on diabetes. Geneva, Switzerland: World Health Organization, 2016.
13. 'IDF Diabetes Atlas'. [Online]. Available: https:// www.idf.org/e-library/epidemiology-research/diabetes-atlas/134-idf-diabetes-atlas-8th-edition. html. [Accessed: 16-Aug-2019].

14. A. D. Association, 'Economic Costs of Diabetes in the U.S. in 2017', Diabetes Care, p. dci180007, Mar. 2018.

https://doi.org/10.2337/dci18-0007

15. L. Heinemann, 'Finger Pricking and Pain: A Never Ending Story', J. Diabetes Sci. Technol. Online, vol. 2, no. 5, pp. 919-921, Sep. 2008. https://doi.org/10.1177/193229680800200526

16. G. Li, S. Wang, and Y. Y. Duan, 'Towards gel-free electrodes: A systematic study of electrode-skin impedance', Sens. Actuators B Chem., vol. 241, pp. 1244-1255, Mar. 2017. https://doi.org/10.1016/j.snb.2016.10.005

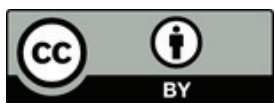

Copyright (c) 2019 by the Authors. This is an open access article distributed under the Creative Commons Attribution (CC BY) License (https://creativecommons.org/licenses/by/4.0/), which permits unrestricted use, distribution, and reproduction in any medium, provided the original work is properly cited.

Arrived: 31. 07. 2019

Accepted: 13. 01. 2020 